\title{
An integrated investigation of lake storage and water level changes in the Paiku Co basin, central Himalayas
}

Yanbin Lei ${ }^{1,2}$, Tandong Yao ${ }^{1,2}$, Kun Yang ${ }^{2,3}$, Broxton W. Bird ${ }^{4}$, Lide Tian ${ }^{1,2}$, Xiaowen Zhang ${ }^{1}$, Weicai Wang ${ }^{1,2}$, Yang Xiang ${ }^{1}$, Yufeng Dai ${ }^{1}$, Lazhu ${ }^{1}$, Jing Zhou ${ }^{1}$, Lei Wang ${ }^{1,2}$

1 Key Laboratory of Tibetan Environment Changes and Land Surface Processes, Institute of Tibetan Plateau Research, Chinese Academy of Sciences, Beijing 100101, China

2 CAS Center for Excellence in Tibetan Plateau Earth System, Beijing, 100101, China

3 Department of Earth System Science, Tsinghua University, Beijing 10084, China

4 Department of Earth Sciences, Indiana University-Purdue University Indianapolis (IUPUI), Indianapolis, IN 46202, USA.

Correspondence to Yanbin Lei, Building 3, Courtyard 16, Lincui Rd, Chaoyang District, Beijing 100101, China. E-mail: leiyb@itpcas.ac.cn

This is the author's manuscript of the article published in final edited form as:

Lei, Y., Yao, T., Yang, K., Bird, B. W., Tian, L., Zhang, X., ... Wang, L. (2018). An integrated investigation of lake storage and water level changes in the Paiku Co basin, central Himalayas. Journal of Hydrology, 562, 599-608. 
Abstract: Since the late 1990s, lakes in the southern Tibetan Plateau (TP) have shrunk considerably, which contrasts with the rapid expansion of lakes in the interior TP. Although these spatial trends have been well documented, the underlying hydroclimatic mechanisms are not well understood. Since 2013, we have carried out comprehensive water budget observations at Paiku Co, an alpine lake in the central Himalayas. In this study, we investigate water storage and lake level changes on seasonal to decadal time scales based on extensive in-situ measurements and satellite observations. Bathymetric surveys show that Paiku Co has a mean and maximum water depth of $41.1 \mathrm{~m}$ and $72.8 \mathrm{~m}$, respectively, and its water storage was estimated to be $109.3 \times 10^{8} \mathrm{~m}^{3}$ in June 2016. On seasonal scale between 2013 and 2017, Paiku Co's lake level decreased slowly between January and May, increased considerably between June and September, and then decreased rapidly between October and January. On decadal time scale, Paiku Co's lake level decreased by $3.7 \pm 0.3 \mathrm{~m}$ and water storage reduced by $(10.2 \pm 0.8) \times 10^{8} \mathrm{~m}^{3}$ between 1972 and 2015, accounting for $8.5 \%$ of the total water storage in 1972 . This change is consistent with a trend towards drier conditions in the Himalaya region during the recent decades. In contrast, glacial lakes within Paiku Co’s basin expanded rapidly, indicating that, unlike Paiku Co, glacial meltwater was sufficient to compensate the effect of the reduced precipitation.

Key words: Paiku Co, lake shrinkage, climate change, central Himalayas, glacial meltwater 


\section{Introduction}

Lakes may respond sensitively to climate change in several aspects of hydrology, biology and sedimentology. Its volume (i.e. levels and areas) may be an important indicator of changes in the water balance between regional precipitation and evaporation, especially for closed lakes in semi-arid regions (Mason et al., 1994; Chen et al., 2017). In cold regions, lake water balance may also be sensitive to cryospheric changes, including glaciers, permafrost and snow cover. Although lake level records are available for some lakes, in-situ measurements remain limited for most lakes, particularly in remote regions, where many closed lakes are located (Lei et al., 2017). Remote sensing is an effective tool to monitor changes in lake area or level on a large scale (Crétaux et al., 2011; Sheng et al., 2016). As more and more satellites are deployed, different kinds of satellite data can be used to depict lake dynamics at higher spatial and temporal resolution (Kleinherenbrink et al., 2015).

The Tibetan Plateau (TP) contains the greatest concentration of high-altitude inland lakes in the world. Since the late 1990s, endorheic lakes in the interior TP have expanded and deepened dramatically, while those in the southern TP have shrunk considerably (Lei et al., 2014), which is generally consistent with changes in regional precipitation and runoff (Yang et al., 2011, 2014). Although in-situ observations of lake hydrology in the TP are labor-intensive and expensive, these data are critical for quantifying lake water budget and distinguishing the contribution of different components to changes in lake level. Until now, in-situ investigations have only been conducted for a few lakes in the interior TP, e.g. Nam Co (Wang et al., 2009; Zhou et al., 2013; Wang et al., 2017) and Siling Co (Guo et al., 2016; Zhou et al., 2015), which are expanding. In contrast, there have been no detailed in-situ investigations to lakes in the southern TP, where most closed lakes 
are shrinking. This situation limits the understanding on the processes controlling lake hydrology and their response to climate change and cryosphere.

Paiku Co is an alpine lake in the the northern slope of central Himalayas on the southern TP, which has shrunk considerably since the 1970s (Phan et al., 2012; Dai et al., 2013; Nie et al., 2013). In contrast, glacial lakes in this region have expanded rapidly in response to glacier retreat (Li et al., 2012; Zhang et al; 2015; Song et al., 2017). Glacier mass balance in this region (Kangwure Glacier) has been observed since 1992 (Ma et al., 2010; Yao et al., 2012; Tian et al., 2014). However, there is still a lack of integrated assessment on changes in water storage in the basin, including the terminal lake, glacial lakes and glaciers. Since 2013, we have carried out a series of in-situ observations associated with the lake's water budget, including lake level, precipitation, runoff, and water temperature profiles in the Paiku Co basin. In this study, we use part of these data to 1) investigate lake bathymetry and seasonal lake level changes, 2) reconstruct inter-annual changes in water level/storage between 1987 and 2016 and decadal changes since 1972, and 3) clarify the long-term climatic (including glacial melt) controls on lake shrinkage in the southern TP.

\section{Study area}

Paiku Co $\left(85^{\circ} 35.12^{\prime} \mathrm{E}, 28^{\circ} 53.52^{`} \mathrm{~N}, 4590 \mathrm{~m}\right.$ a.s.l) is a large alpine lake in the southern TP, which was tectonically formed along Jilong-Dingri fault zone in the central Himalayas (Wünnemann et al., 2015). The lake, with surface area of $270 \sim 280 \mathrm{~km}^{2}$ and catchment area of $2376 \mathrm{~km}^{2}$ (including the lake), is hydrologically closed with evaporation as the primary pathway of water loss. The lake 
has salinity of about $1.7 \mathrm{~g} / \mathrm{L}$ and $\mathrm{pH}$ of 9.0 (measured in 2015). There are tens of visible paleo-shorelines around Paiku Co with the highest shoreline $\sim 80 \mathrm{~m}$ above the modern lake level, indicating that the lake has been shrinking since early Holocene (Wünnemann et al., 2015). To the south of the lake, there are several high mountains reaching more than $7000 \mathrm{~m}$ a.s.l (Fig. 1), including Xixiabangma Mt. (peak at $8012 \mathrm{~m}$ a.s.1.) to the southeast (Shi and Liu, 1964). According to the second Chinese glacier inventory (Wei et al., 2014), a total of 41 glaciers are distributed in the catchment in $\sim 2010$, covering a total area of $\sim 123 \mathrm{~km}^{2}$. The terminus of modern glaciers is generally higher than $\sim 5500$ a.s.l (Liu et al., 2011). Approximately 11 glacial outflow lakes in the basin can be identified in Landsat images spanning 2012-2016, nine of which are close to or connected with glacial terminus (Fig. 1). Paiku Co is mainly supplied by three large rivers (Fig. 1), Daqu (glacier-fed, $450 \mathrm{~km}^{2}$ ), Laqu (glacier-fed, $325 \mathrm{~km}^{2}$ ) and Barixiongqu(non-glacier-fed, 703 $\left.\mathrm{km}^{2}\right)$

Climate in Paiku Co basin is mainly influenced by the westerlies in winter (October and April) and Indian summer monsoon in summer (May and September), and thus is characterized by a relatively warm and wet summer and a cold and dry winter. According to rain gauge data collected between 2013 and 2016, seasonal and annual rainfall in the Paiku Co basin fluctuated significantly year to year. Generally, annual precipitation varied between 150 200 mm with snowfall in winter accounting for less than $10 \%$ of annual total. However, in unusual years, snowfall associated with the Indian monsoon precipitation (Tian et al., 2012) could account for more than half of annual precipitation (e.g. 2014). The mean annual air temperature at Paiku Co was $4.4^{\circ} \mathrm{C}$ in $2015 / 2016$. Daily mean temperatures below zero occur between November and March. Climate warming has been significant in this region. The mean annual air temperature at Tingri County, $150 \mathrm{~km}$ to east 
of Paiku Co, increased rapidly at a rate of $0.40{ }^{\circ} \mathrm{C}$ per decade between 1970 and 2015. On seasonal time scale, the highest temperatures occur in July $\left(\sim 15^{\circ} \mathrm{C}\right)$, and the lowest temperatures occur in January $\left(\sim-8^{\circ} \mathrm{C}\right)$. Daily mean temperatures below zero occur between November and March.

\section{Methods}

\subsection{Lake bathymetry}

Bathymetric survey of Paiku Co was mainly conducted over a three-day period in early June 2016.

Lake bathymetry was measured along more than 10 transects that were spatially distributed across the whole lake (Fig. 2). Water depth was determined with a vertical accuracy of $0.1 \mathrm{~m}$ and horizontal accuracy of $3 \mathrm{~m}$ using a 500 watt duel frequency depth sounder interfaced with a Garmin GPSMAP 421S chart plotter. Latitude, longitude, and water depth were acquired at 5-second intervals along each bathymetric transect. A total of 8050 water depth data points were acquired. The lake boundary in May 2015 was used to calculate lake water storage. The lake's morphometry was established by interpolating water depth data to the whole lake using spatial analyst tools (Topo to Raster) in ArcGIS 9.2 and the lake volume was calculated according to the underwater topography and surface area (Qiao et al., 2017).

\subsection{Lake level monitoring}

In-situ observations of lake level changes were conducted using HOBO water level loggers (U20-001-01) that were installed at the littoral zone of Paiku Co (Fig. 1). Three loggers were installed at the north, west and east of the lake in 2013/2014, respectively. Unfortunately, the loggers at the west and east of the lake were lost and only the logger at the north of the lake 
continually recorded the lake level changes since May 2013. The logger data were downloaded twice a year (May and October). Because the water levels were recorded as changes in pressure (with an accuracy of $0.5 \mathrm{~cm}$ water level equivalent), air pressure data from a nearby land-based logger was subtracted from the lake level loggers to isolate pressure changes related to water column variations. Here we use daily lake level changes between 2013 and 2017 and the average lake area to calculate seasonal changes in lake storage at Paiku Co (Fig. 3).

\subsection{Investigation of lake shorelines and reconstruction of long-term lake level changes}

In June 2016, we investigated the lake shoreline located to the southeast of the lake (Fig.1). Visible past shorelines near the modern lake were observed during the fieldwork (Fig. 4a). The location of all identifiable shorelines was determined using portable GPS (Garmin GPS 60) with an error of less than $3 \mathrm{~m}$ in horizontal and their height above the modern lake level was measured with a laser rangefinder. Combined with earlier satellite images taken from 1972 to present, lake level changes relative to the modern lake level (June 2016) were reconstructed (Fig. 4c). A relationship between lake area and the relative lake level changes was established by using a two-order polynomial regression (Fig. 4d).

\subsection{Satellite images}

Landsat images from May and October were used to study changes in lake area (http://glovis.usgs.gov). When there is no data available in the two months, images in the adjacent months are also used (Tab.1). A total of 54 satellite images were selected to explore the continual lake area change between 1987 and 2016 (with an absence of spring 1987, 2003 and the autumn 1990). Usually, the lake level is highest in September and lowest in May, so the lake area in the two periods can approximately represent the maximum and minimum lake area in a year. The 
seasonal and inter-annual lake level changes were reconstructed based on the relationship between lake area and water level described in section 3.3 (Fig. 5).

Changes in glacier area in the Paiku Co basin were analyzed based on the topography maps in the 1970s and the second Chinese glacier inventory in 2009 (Wei et al., 2014). Glacial lakes in the Paiku Co basin were extracted from Landsat images at 5-year interval and changes in lake area are analyzed (Tab. 2). Two small closed lakes nearby Paiku Co, Langqiang Co $\left(85^{\circ} 52.65^{\prime}\right.$ E, 28 $\left.{ }^{\circ} 43.41^{\prime} \mathrm{N}\right)$ and Cuojielong $\left(85^{\circ} 23.966^{\prime} \mathrm{E}, 28^{\circ} 7.31^{\prime} \mathrm{N}\right)$, were also delineated at 5-year interval to compare with Paiku Co (Fig.1). The images have been orthorectified and geometrically corrected using an UTM projection in WGS84 datum. Lake boundaries were extracted in false color image by manual delineation using ArcGIS 9.2 software.

Satellite altimetry data, including ICESat and Cryosat-2 were used to validate the reconstructed lake level changes. Lake level at Paiku Co was detected by ICESat satellite twice to three times a year with decimeter precision between 2003 and 2009. Since 2011, it was monitored by Cryosat-2 satellite at higher temporal resolution (Kleinherenbrink et al., 2015). The combination of the two dataset provides a good chance to validate the reconstructed lake level changes since 2003 (Fig. 5), although there is a gap between the two dataset. The ICESat data used in this study was processed by Li et al (2014) and Cryosat-2 data was processed by Kleinherenbrink et al. (2015).

\section{Results}

\subsection{Lake bathymetry and water storage}

Consistent with its tectonic origin, Paiku Co's bathymetry (Fig. 2) is characterized by a steep 
littoral zone with rapidly increasing water depths, which reach more than $30 \mathrm{~m}$ within several hundred meters from the shoreline. In the southern part of the lake basin, where the main river estuaries are located, water depths increase gradually to more than $50 \mathrm{~m}$ from south to north. In the northern lake basin, the bottom is flat and the water depth is generally more than $60 \mathrm{~m}$ with a maximum depth of $72.8 \mathrm{~m}$. The total water storage of Paiku Co is estimated to be $109.3 \times 10^{8} \mathrm{~m}^{3}$ with an average water depth of $41.1 \mathrm{~m}$. As a deep alpine lake, $53.8 \%$ of the lake water area is deeper than $40 \mathrm{~m}$ and water volume below $40 \mathrm{~m}$ accounts for about $22.0 \%$ of the total lake storage. Compared with other large lakes on the TP, Paiku Co has similar maximum water depth with Mapam Yumco and Zhari Namco (Wang et al., 2010 and 2013), but its mean water depth is greater than the two lakes because of its steep shoreline.

\subsection{Observed lake level seasonality}

The observed lake level changes at Paiku Co exhibit a marked seasonal cycle for each of the years investigated (Fig. 3). Catchment-scale hydrological processes in this high elevation region can thus be identified by the detailed lake level changes. The lake level trends below are for 2013 to 2017, unless otherwise noted.

Beginning after lake ice break-up in mid-April, Paiku Co's lake level decreased slowly until the onset of Indian summer monsoon in June. The mean rate of lake level decrease varied in a range of 1.1 1.5 mm per day $(6 \sim 7 \mathrm{~cm}$ in total) between 15 April and 31 May. The slow rate of lake level decline in the spring is consistent with the modeling result of lake evaporation, which shows that lake evaporation is much lower in spring than that in autumn due to the large heat storage of lake water, especially for deep lakes (Haginoya et al., 2009; Lazhu et al., 2016). However, it should be noted that lake level decrease in spring is influenced by the amount of snow melting in addition to 
evaporation. For example, lake levels were almost stable in spring 2015 when winter snowfall was much greater than average $(\sim 90 \mathrm{~mm} v s \sim 10 \mathrm{~mm})$. As a result, snowfall melt in spring compensated for water loss from lake evaporation, maintaining a relatively stable lake level.

Between early June and early September, lake levels increased significantly, corresponding to the occurrence of Indian summer monsoon precipitation. Lake levels started to increase significantly since early June, reaching their highest levels in mid-September. Lake levels increased at an average rate of $3.6 \sim 5.9 \mathrm{~mm}$ per day between June 1 and September $15(37 \sim 58 \mathrm{~cm}$ in total), corresponding to lake storage increase of $1.0 \sim 1.6 \times 10^{6} \mathrm{~m}^{3}$ per day. The extent of lake level increase during this period, however, depended on the duration and amount of monsoonal rainfall. In summer 2015, for example, the lake levels increased by $37 \mathrm{~cm}$ in total $(3.6 \mathrm{~mm}$ per day) when monsoonal precipitation was the lowest $(70 \sim 80 \mathrm{~mm})$, while in summer 2016, lake levels increased by $58 \mathrm{~cm}$ in total $(5.9 \mathrm{~mm}$ per day) when monsoonal precipitation was the greatest $(\sim 200 \mathrm{~mm})$. Notably, glacial meltwater from the high mountain areas peaks during the summer as temperature rises, thereby also contributing to summer lake level increase.

Lake levels remained high between early September and early October, with some fluctuations in early October. This fluctuation is mainly attributed to heavy snowfall events, which were observed during the fieldwork. For example, the lake level increased suddenly by $3 \sim 4 \mathrm{~cm}$ on Oct 14, 2014, due to a heavy snowfall in the catchment. Between September 20 and January 10, the lake level decreased rapidly at an average rate of $2.6 \sim 3.4 \mathrm{~mm}$ per day (30 38 $\mathrm{cm}$ in total), corresponding to reduction in lake storage by $0.7 \sim 0.9 \times 10^{6} \mathrm{~m}^{3}$ per day. The rapid decreasing rates were mainly caused by high lake evaporation (Haginoya et al., 2009; Lazhu et al., 2016) and low water input during this period. 
Lake levels were almost stable during the winter from mid-Jan to mid-April as ice cover largely precluded lake water evaporation. In 2013/2014, the lake level decreased by $3 \sim 4 \mathrm{~cm}$ during the ice cover period (mid-January to mid-April). Exceptions occurred during the winters of 2015/2016 and 2016/2017, when the lake surface was not covered by ice as indicated from 16-day Landsat images. The lake level decreased considerably at a rate of $1.2 \mathrm{~mm} /$ day (16 $\mathrm{cm}$ in total) between Jan 16 and April 15, which led to a greater lake level reduction in the winters of 2015/2016 and $2016 / 2017$ relative to the previous two years. The rate of lake level decrease in the winter is comparable to that after lake ice break-up in mid-April.

Lake level seasonality in the TP has only been reported for a few lakes (Zhou et al., 2013; Lei et al., 2017). Lei et al (2017) found that there are two patterns of the lake level seasonality in the TP. Paiku Co exhibits similar lake seasonality with the two large lakes in the central TP, Nam Co and Zhari Namco, in both magnitude and pace. As for the decreasing rate between October and December, we compared Paiku Co with the lake level changes at Zhari Namco and found it varied between $2.5 \sim 3.0 \mathrm{~mm} / \mathrm{day}$, which is slightly less than that of Paiku Co. However, for the smaller lakes, Dawa Co and Bam Co, although there was a similar pattern of lake seasonality, the amplitude of seasonal lake level fluctuations was considerably smaller than that of Paiku Co.

\subsection{Long-term changes in lake level and storage}

Here we reconstructed lake level changes of Paiku Co based on in-situ investigations of past lake shoreline in combination with satellite images (e.g. Lei et al., 2014). Lake level in 1972, 1988, 1994, 2001 and 2006 relative to the modern lake level (June 2016) were measured in the fieldwork according to the shoreline position derived from Landsat images (Fig. 4c). The results show that the shoreline retreated by $460 \mathrm{~m}$ and the lake level decreased by $3.7 \pm 0.3 \mathrm{~m}$ from 1972 to June 
2016. This result is similar with our previous estimate according to the fieldwork at another site of Paiku Co in 2013 (Fig. 1), which showed that the lake level decreased by $4.0 \mathrm{~m}$ from 1976 to 2010 (Lei et al., 2014).

We further established the relationship between lake area and water level changes and reconstructed the intra-annual changes in lake level between 1987 and 2016. Fig. 4d shows that the relative lake levels at different periods were well correlated with the corresponding lake area $\left(r^{2}=0.99\right)$. The relationship between lake area and water level changes was developed by using a two-order polynomial regression rather than linear regression because the latter may lead to larger error for some lakes (Crétaux et al., 2016). Using this equation, the intra-annual and inter-annual lake level changes between 1987 and 2016 were reconstructed according to the satellite-derived lake area.

Since most of the satellite images we used in this study were taken in May and Oct (Tab. 1), the reconstructed lake levels represent the lowest and highest lake levels for each year. Although there is slight difference, the highest and lowest lake levels decreased at a similar trend of $0.086 \mathrm{~m}$ per year on average between 1987 and 2016 (Fig. 5). The seasonal lake level fluctuations as indicated by the difference between the highest and lowest lake level were $36 \mathrm{~cm}$ on average between 1987 and 2016, corresponding to changes in lake storage of $1.0 \times 10^{8} \mathrm{~m}^{3}$.

Between 1972 and 2016, Paiku Co's surface area decreased by $11.6 \mathrm{~km}^{2}(4.1 \%)$. The lake storage of Paiku Co decreased from $119.5 \times 10^{8} \mathrm{~m}^{3}$ to $109.3 \times 10^{8} \mathrm{~m}^{3}$, with an average rate of $0.24 \times 10^{8} \mathrm{~m}^{3}$ per year. One can find that the seasonal fluctuations of lake storage were much larger than that on inter-annual time scale. The total lake storage reduced by $10.2 \times 10^{8} \mathrm{~m}^{3}$, or $8.5 \%$ of the total storage over the past 45 years. Changes in lake storage can be divided into four periods. Lake storage 
decreased at a rate of $0.3 \times 10^{8} \mathrm{~m}^{3}$ per year between 1972 and 1992 , turned to increase at a rate of $0.4 \times 10^{8} \mathrm{~m}^{3}$ per year between 1993 and 1997 , decreased again at rate of $0.4 \times 10^{8} \mathrm{~m}^{3}$ per year between 1998 and 2008, and became almost stable between 2009 and 2016.

\section{Discussion on lake shrinkage of Paiku Co}

As a hydrologically-closed alpine lake, changes in lake level at Paiku Co are mainly associated with glacier/snow runoff, precipitation on the lake surface, precipitation-induced runoff and lake evaporation. Lake evaporation and groundwater will be investigated using energy and water budget method in another study. Here we main demonstrate how precipitation and glacier runoff affected the lake shrinkage of Paiku Co during the past 45 years.

\subsection{Evaluation of the reconstructed lake level changes}

The error of the reconstructed lake level changes mainly comes from the identification of past shorelines, which are determined according to field GPS measurements and previous satellite images. The error of GPS measurements is small compared to the retreat of shorelines and therefore can be neglected. Since the Landsat images we used have a resolution of $30 \mathrm{~m}(60 \mathrm{~m}$ in the 1970s), there may be an error in identifying previous shorelines. Since $460 \mathrm{~m}$ of shoreline retreat corresponds to $3.7 \mathrm{~m}$ of lake level decrease, an error of $30 \mathrm{~m}$ (60 m in the 1970s) in horizontal distance can cause an error of $0.3 \mathrm{~m}(0.6 \mathrm{~m}$ in the $1970 \mathrm{~s})$ in the vertical changes in lake level, which corresponds to an error of $0.8 \times 10^{8} \mathrm{~m}^{3}$ in lake storage.

\subsection{Comparison with satellite altimetry data}

To verify our results, we first compare the reconstructed lake level changes with satellite altimetry 
data (Fig. 5). Paiku Co’s water level was monitored by both ICESat (2003-2009) (Phan et al., 2012; Li et al., 2014) and Cryosat satellites (since 2011) (Kleinherenbrink et al., 2015). Fig. 5b shows that although there are some differences between the reconstructed lake level and satellite altimetry, they exhibit very similar fluctuations on both seasonal and inter-annual time scales (Fig. 5b). The reconstructed lake levels also match well with the observed lake level changes between 2013 and 2016 (Fig. 5b).

Besides in-situ measurements and satellite observations, there are several other methods for reconstructing past lake level changes (Zhang et al., 2011; Meng et al., 2011; Lei et al., 2013). Song et al (2013) estimated long-term water level/storage changes on the TP by establishing an empirical model between ICESat altimetry data and lake area from 2003 to 2009. Using this method, Zhao et al (2016) estimated the lake level drop of Paiku Co to be $2.1 \mathrm{~m}$ between 1991 and 2014, which is similar with our result $(2.0 \mathrm{~m})$ during the same period. However, our estimation of water level changes was considerably larger than the result by Zhang et al (2014), who used six years of experiment data (2003-2009) to extend the lake level change for the last 40 years. This indicates that caution should be taken when extending the lake level fluctuation by using only short-term data.

\subsection{Glaciers and glacial lake changes within the basin}

Glacial melt in the basin is reflected by glacier mass balance observation and glacial lake dynamics. During the past 40 years, glaciers in the central Himalayas retreated and thinned rapidly (Yao et al., 2012; Bolch et al., 2012). According to the topography maps in the 1970s and the second Chinese glacier inventory in 2009 (Wei et al., 2014), the total glacier area in Paiku Co 
basin decreased from $130.2 \mathrm{~km}^{2}$ to $119.9 \mathrm{~km}^{2}$ during the past 40 years. Taking Kangwure Glacier as an example (Fig. 1), Ma et al (2010) showed the significant decreases in glacier area (34\%), thickness $(7.5 \mathrm{~m})$ and volume (48\%) between the 1970s and 2008. Using differential GPS, Tian et al (2014) found that the thickness of Kangwure Glacier reduced by $2.3 \sim 3.1 \mathrm{~m}$ at eight points with an annual average of $0.8 \mathrm{~m} / \mathrm{yr}$ from September 2007 to August 2010. Long-term glacier mass balance reconstruction showed that the thickness of Kangwure glacier decreased by $0.5 \mathrm{~m} / \mathrm{yr}$ on average between 1992 and 2010 (Yao et al., 2012).

Consistent with the observation of rapid glacier retreat, glacial lakes have undergone a rapid expansion since the 1970s. Based on Landsat images from the 1970s to present, we detected that nine glacial lakes in the catchment are connected with or close to glacier terminus (Fig. 1; Tab. 2). Of these nine lakes, three of them appeared after the 1990s (Lake 0\#, 5\# and 6\#). The total area of glacial lakes in the Paiku Co watershed increased by $43.4 \%$ (or $4.5 \mathrm{~km}^{2}$ ) from 1976 to 2015. Since glacial lakes and glaciers are connected, the glacial lake expansion largely depended on glacial retreat because the latter can leave space for glacial lakes to expand, yet result in no obvious lake level increase (Fig. 6). In turn, the appearance of glacial lakes could lead to the acceleration of glacier retreat by transmitting thermal energy (e.g. lake 6\#) (Song et al., 2017). When glaciers retreated to higher elevation and were no longer connected with glacial lake, the latter will become stable (e.g. lake 4\#).

The contrasting pattern between the glacial lakes and Paiku Co indicates that there are different factors that influence lake storage changes. For glacial lakes, its expansion mainly depended on the rapid glacier retreat. At first, the appearance of glacial lake will accelerate the glacial melting. Under this condition, glacier retreated rapidly and the glacial lake expanded rapidly. When the 
glacier retreated to higher elevation and is no longer connected with glacial lake, the latter will keep relatively stable. However, the water supply for Paiku Co is more complicated, including not only glacial meltwater, but also precipitation and the associated runoff in non-glaciated area. The continual water deficit of Paiku Co indicates that although there was an increase in glacial runoff during the past 45 years, it was not sufficient to offset the water deficit caused by other climate factors.

\subsection{Precipitation changes in the central Himalayas}

Changes of regional precipitation in the central Himalayas are demonstrated by meteorological data and ice core accumulation records. There is no meteorological station in Paiku Co basin, and two closest meteorological stations are located in Nyalam and Tingri Counties, which are $80 \mathrm{~km}$ and $150 \mathrm{~km}$ away from Paiku Co, respectively. Precipitation data at the two stations were used to analyze the regional precipitation changes. Ice core accumulation rates were also used to reflect regional precipitation changes in high elevation areas. One such record is Dasuopu ice core (7200 a.s.l.), which lies to the east of Paiku basin and was drilled in 1997. Annual net accumulation during the past 1000 years was reconstructed (Thompson et al., 2000). The other is the East Rongbuk Col ice core on Mount Everest (6500a.s.l), which lies $130 \mathrm{~km}$ to the east of Dasuopu glacier and was drilled in 2002. Annual net accumulation between AD1534 and 2001 was reconstructed (Kaspari et al., 2008).

The annual net water equivalent accumulation from the Dasuopu ice core was about $890 \mathrm{~mm} / \mathrm{yr}$ on average between 1970 and 1996. This value is 3 to 4 times higher than the rain gauge data in Paiku Co basin (150-200 mm), which indicates that precipitation at high elevation may play an important role in river runoff. Although the whole study period is not covered, the net 
accumulation from the two ice cores showed a marked decreasing trend between 1970 and 1996 (Fig. 7). Ice core accumulation at Mount Everest region and precipitation in Nyalam County exhibits similar inter-annual variability, especially the abrupt decrease in $\sim$ the early 1990s (Fig. 7). Precipitation in Nyalam County covers the whole study period and a pronounced decreasing trend can be observed between 1970 and 2016, although the decreasing trend is smaller than that of Dasuopu ice core. Notably, precipitation in Tingri County did not exhibit noticeable trend, indicating a significant spatial difference in this area. Therefore, the significant decrease in precipitation and the associated runoff may contribute significantly to the shrinkage of Paiku Co during the past 40 years. It should be noted that lake evaporation at Paiku Co is not determined in this study, its contribution to lake shrinkage will be evaluated in further study.

Many studies have shown that closed lakes in the northern slope of Himalayas have decreased in areal extent and water level in recent decades (e.g. Bian et al., 2009; Phan et al., 2012; Nie et al., 2013; Lei et al., 2014; Biskop et al., 2016). Therefore, Paiku Co can be considered as a case study of the lake shrinkage in this region. To illustrate the causes of closed lake shrinkage in the Himalaya region, GPCP gridded precipitation dataset on large scale is analyzed. Fig. 8 shows the trend of GPCP precipitation in Himalaya region and its surroundings. One can find that there was a significant decrease in precipitation in Nepal Himalaya and north Indian, in addition to the northern slope of the Himalayas. Lake shrinkage in the northern slope of Himalayas may be only part of the large-scale climate drought, which is further connected with a decrease in monsoon precipitation in south Asia (Wang et al., 2012). Besides GPCP precipitation data, this recent drought in Himalaya region was also revealed by many studies (e.g. Thompson et al., 2000; Duan et al., 2006; Panthi et al., 2017). The spatial patterns of changes in precipitation were consistent 
with lake dynamics between the Himalayas and the interior TP (Lei et al., 2014). This result also indicates that the water level change at Paiku Co is not only a good indicator of climate drying in the central Himalayas, but also reflects large-scale changes in monsoon precipitation in south Asia (Thompson et al., 2000; Duan et al., 2006).

\subsection{Long-term changes of adjacent lakes}

The combined effect of long-term changes in precipitation, precipitation-induced runoff and evaporation on lake water budget can be reflected by adjacent lake dynamics with little glacial melt supply. Lake Cuojielong, with an area of $11.5 \mathrm{~km}^{2}$ in 2016 , is located about $15 \mathrm{~km}$ to northwest of Paiku Co (Fig. 1). The lake is mainly supplied by precipitation and precipitation-induced runoff, and there is only a small glacier $\left(\sim 0.5 \mathrm{~km}^{2}\right)$ in the catchment. Like Paiku Co, Lake Cuojielong shows considerable lake shrinkage between 1972 and 2015 (Fig. 9). Since there is almost no glacial melt supply, Lake Cuojielong's shrinkage further confirms that the continual water deficit was caused by regional decrease in precipitation and precipitation-induced runoff during the past 40 years.

Langqiang Co, with an area of $24 \mathrm{~km}^{2}$ in 2016, lies about $19 \mathrm{~km}$ to the east of Paiku Co. It is mainly supplied by glacial meltwater from Xixiabangma Glacier. The lake first expanded between 1972 and 2000, and then shrank quickly in the 2000s. In the 2010s, it turned to expand slightly. The different process of lake dynamics between Lake Cuojielong and Lake Langqiang Co may be attributed to a greater contribution of glacial melt to the latter as well as subsurface runoff given its proximity to the Pengqu River. Field investigation of the lake indicates that lake water could overflow through a trail along the lake's south shore when the lake level is over a certain height in summer season. 


\section{Conclusions}

To fully understand the lake water budget at Paiku Co, an alpine lake in the central Himalayas, we carried out comprehensive observation since 2013, including lake bathymetry, lake level, precipitation, runoff and evaporation. In this study, we mainly investigate lake bathymetry and water level changes on seasonal to decadal time scales at the Paiku Co basin. The results show that water storage at Paiku Co is estimated to be approximately $109.3 \times 10^{8} \mathrm{~m}^{3}$. The lake level decreased considerably by $3.7 \pm 0.3 \mathrm{~m}$ between 1972 and June 2016, resulting in lake storage reduction by $(10.2 \pm 0.8) \times 10^{8} \mathrm{~m}^{3} \mathrm{~m}^{3}(8.5 \%$ of the total storage). Seasonal lake level changes are characterized by a marked increase during the monsoon season, which are then followed by a significant lowering during the early winter. Stable lake levels are observed in winter when ice cover precludes evaporative losses. In spring, lake levels continue to decrease slightly before their subsequent rise during the next monsoon season. Monsoon precipitation has been decreasing during the last decades, as a result, has not been sufficient to offset evaporative losses, thereby resulting in long-term water deficit at Paiku Co. While increase in glacial melt has led to the expansion of glacial lakes, its contribution to Paiku Co was not sufficient to offset the impacts of the reduced precipitation. On a large spatial scale, the shrinkage of Paiku Co can not only be considered be as an indicator of climate drying in the central Himalayas, but also reflects large-scale changes in monsoon precipitation in south Asia.

Acknowledgement: This research has been supported by the NSFC project (41571071 and 
21661132003), the Research Program of the Chinese Academy of Sciences (XDB03030207 and QYZDY-SSW-DQC003), and Youth Innovation Promotion Association CAS. We thank Qomolangma Atmospheric and Environmental Observation and Research Station CAS for providing meteorological data. We are grateful to all the members who took part in the fieldwork.

\section{References}

Bian, D., Du, J., Hu, J., 2009. Response of the water level of the Yamzho Yumco to climate change during 1975-2006. J. Glaciol. Geocryol. 31(3), 404-409.

Biskop, S., Maussion, F., Krause, P., Fink, M., 2016. What are the key drivers of regional differences in the water balance on theTibetan Plateau? Hydrol. Earth Syst. Sci. 20, 209-225.

Bolch, T., et al., 2012. The state and fate of Himalayan glaciers. Science, 336(6079), 310-314.

Chen, J.L., Pekker T., Wilson C.R., Tapley B.D., Kostianoy A.G., Cretaux J.-F., and Safarov E.S., 2017. Long-term Caspian Sea level change, Geophys. Res. Lett. 44, 6993-7001.

Crétaux, J.F., Jelinski, W., Calmant, S., 2011. SOLS: A lake database to monitor the Near Real

Time water level and storage variations from remote sensing data. Adv. Space Res. 47, $1497-1507$.

Crétaux J.F., Abarca-del-Río R., Bergé-Nguyen M., Arsen A., Drolon V., Clos G., Maisongrande P., 2016. Lake Volume Monitoring from Space. Surv. Geophys. 37, 269-305.

Dai, Y., Gao, Y., Zhang, G., et al., 2013. Water volume change of the Paiku Co in the southern Tibetan Plateau and its response to climate change in 2003-2011. J. Glaciol. Geocryol. 35 (3), 723-732. 
Duan, K., Yao T., and Thompson L.G., 2006. Response of monsoon precipitation in the Himalayas to global warming. J. Geophys. Res. 111, D19110, doi:10.1029/2006JD007084

Guo, Y., Zhang, Y., Ma, N., Song, H., Gao, H., 2016. Quantifying surface energy fluxes and evaporation over a significant expanding endorheic lake in the central Tibetan Plateau. J. Meteorol. Soc. Jap. 94 (5), 453-465.

Haginoya, S., Fujii, H., Kuwagata, T., Xu J., Ishigooka Y., Kang S., and Zhang Y., 2009. Air-Lake Interaction Features Found in Heat and Water Exchanges over Nam Co on the Tibetan Plateau. SOLA, 5, 172-175, doi:10.2151/sola.2009-044.

Kaspari, S., Hooke, R.L., Mayewski, P., Kang, S., Hou, S., Qin, D., 2008. Snow accumulation rate on Qomolangma (Mount Everest), Himalaya: synchroneity with sites across the Tibetan Plateau on 50-100year timescales. J. Glaciol. 54 (185), 343-352.

Kleinherenbrink, M., Lindenbergh, R.C., Ditmar, P.G. 2015. Monitoring of lake level changes on the Tibetan Plateau and Tian Shan by retracking Cryosat SARIn waveforms. J. Hydrol. 521, $119-131$.

Lazhu, Yang, K., Wang, J., Lei, Y., Chen, Y., Zhu, L., Ding, B., and Qin, J. 2016. Quantifying evaporation and its decadal change for Lake Nam Co, central Tibetan Plateau. J. Geophys. Res. Atmos., 121, doi:10.1002/2015JD024523

Lei. Y., Yao. T., Bird. B.W., Yang, K., Zhai, J., and Sheng, Y. 2013. Coherent lake growth on thecentral Tibetan Plateau since the 1970s: characterization and attribution. J. Hydrol. 483,61-67. Lei, Y., Yang, K., Wang, B., Sheng, Y., Bird, B. W., Zhang, G., and Tian, L., 2014. Response of inland lake dynamics over the Tibetan Plateau to climate change. Climatic Change. 125, 281-290. 
Lei, Y., Yao, T., Yang, K., Sheng, Y., Kleinherenbrink, M., Yi, S., Bird, B., Zhang, X., Zhu, L., and Zhang, G. 2017. Lake seasonality across the Tibetan Plateau and their varying relationship with regional mass changes and local hydrology. Geophys. Res. Lett. 44, doi:10.1002/2016GL072062.

Li, J., Sheng, Y., 2012. An automated scheme for glacial lake dynamics mapping using Landsat imagery and digital elevation models: a case study in the Himalayas. Int. J. Remote Sens. 33 (16), 5194-5213.

Li, S.H., Yao, T.D., Tian, L.D., Wang, P., 2011. Seasonal transition characteristics of the westerly jet: Study based on field observations at an altitude of $6900 \mathrm{~m}$ on the Mt. Xixiabangma Dasuopu glacier. Chinese Sci. Bull. 56, 1912-1920, doi: 10.1007/s11434-011-4508-x.

Li, Y., Liao, J., Guo, H., Liu, Z., Shen, G., 2014, Patterns and potential drivers of dramatic changes in Tibetan lakes, 1972-2010. PLoS ONE, 9(11): e111890. doi:10.1371/journal.pone.0111890.

Liu, G.N., Li, Y.K., Chen, Y.X., Zhang, M., Li, C.C., Kong, P., Harbor, J., Caffee,M.W. 2011. Glacial landform chronology and environment reconstruction of Peiku Gangri, Himalayas. J. Glaciol. Geocryol. 33 (5), 959-970.

Ma, L., Tian, L., Pu, J. and Wang, P. 2010. Recent area and ice volume change of Kangwure Glacier in the middle of Himalayas. Chinese Sci. Bull. 55(20), 2088-2096.

Mason, I.M., Guzkowska, M.A.J., Rapley, C.G., Street-Perrot, F.A. 1994. The response of lake levels and areas to climate change. Climatic Change. 27,161-197.

Meng, K., Shi, X., Wang, E., Liu, F. 2011. High-altitude salt lake elevation changes and glacial ablation in Central Tibet, 2000-2010. Chin. Sci. Bull. 57(7), 571-579.

Nie, Y., Zhang, Y., Ding, M., Liu, L., Wang, Z. 2013. Lake change and its implication in the 
vicinity of Mt. Qomolangma (Everest), central high Himalayas, 1970-2009. Environ. Earth Sci. $68,251-265$.

Panthi, S., Bräuning, A., Zhou, Z., Fan, Z., 2017. Tree rings reveal recent intensified spring drought in the central Himalaya, Nepal. Global Planet. Change. 157, 26-34.

Phan, V.H., Lindenbergh, R., Menenti, M. 2012. Seasonal Trends in Tibetan Lake Level Changes as Observed by ICESat Laser Altimetry. ISPRS Annals of the Photogrammetry, Remote Sensing and Spatial Information Sciences, Melbourne, Australia, 237-242.

Qiao, B., Zhu, L., Wang, J., Ju, J., Ma, Q., Liu, C., 2017. Estimation of lakes water storage and their changes on the northwestern Tibetan Plateau based on bathymetric and Landsat data and driving force analyses. Quatern. Int. 454, 56-67.

Sheng, Y., Song, C., Wang, J., Lyons, E.A., Knox, B.R., Cox, J.S., Gao, F., 2016. Representative lake water extent mapping at continental scales using multi-temporal Landsat-8 imagery. Remote Sens. Environ. 185, 129-141.

Shi, Y., Liu, T., 1964. Preliminary report on the Mount ShishaPangma. Kexue Tongbao (Chinese Science Bulletin). 9(10): 928-938.

Song, C., Huang, B., Ke, L., 2013. Modeling and analysis of lake water storage changes on the Tibetan Plateau using multi-mission satellite data. Remote Sens. Environ. 135, 25-35.

Song, C., Sheng, Y., Wang, J., Ke, L., Madson, A., Nie, Y., 2017. Heterogeneous glacial lake changes and links of lake expansions to the rapid thinning of adjacent glacier termini in the Himalayas. Geomorphology. 280, 30-38.

Tian, L., Yao, T., Wen, R., Weng, Y., Zhao, Z., Qu, D., 2012. A primary recognition on the climatic significance of ice core isotope record in Naimona'ny of wester Tibetan Plateau. Quatern. 
Sci. 32(1), 46-52.

Tian, L., Zong, J., Yao, T., Ma, L., Pu, J., Zhu, D., 2014. Direct measurement of glacier thinning on the southern Tibetan Plateau (Gurenhekou, Kangwure and Naimona'Nyi glaciers). J. Glaciol. 60 (223), 879-888.

Thompson, L.G., T. Yao, E. Mosley-Thompson, M.E. Davis, K.A. Henderson and Lin, P., 2000. A high-resolution millennial record of the south Asian monsoon from Himalayan ice cores. Science, 289(5486), 1916-1919.

Wang, B., Ma Y., Ma W., and Su Z., 2017. Physical controls on half-hourly, daily, and monthly turbulent flux and energy budget over a high-altitude small lake on the Tibetan Plateau, J. Geophys. Res. Atmos., 122, 2289-2303.

Wang, B., Liu, J., Kim, H.J., Webster, P.J., Yim, S.Y., 2012. Recent changes of the global monsoon precipitation (1979-2008). Clim. Dyn. 39(5):1123-1135.

Wang, J., Zhu, L., Daut, G., Ju, J., Lin, X., Wang, Y., Zhen, X., 2009. Investigation of bathymetry and water quality of lake Nam Co, the largest lake on the central Tibetan Plateau, China. Limnology 10, 149-158.

Wang, J., Peng, P., Ma, Q., Zhu, L., 2010. Modern limnological features of Tangra Yumco and Zhari Namco, Tibetan Plateau. J. Lake Sci. 22(4), 629-632.

Wang, J., Peng, P., Ma, Q., Zhu, L., 2013. Investigation of water depth, water quality and modern sedimentation rate in Mapam Yumco and La'ang Co, Tibet. J. Lake Sci. 25(4), 609-616.

Wei, J., Liu, S., Guo, W., 2014. Surface-area changes of glaciers in the Tibetan Plateau interior area since the 1970s using recent Landsat images and historical maps. Ann. Glaciol. 55(66), 213-222. 
Wünnemann, B., Yan, D., Ci, R. 2015. Morphodynamics and lake level variations at Paiku Co, southern Tibetan Plateau, China. Geomorphology. 246, 489-501.

Yao, T.D., et al., 2012. Different glacier status with atmospheric circulations in Tibetan Plateau and surroundings. Nat. Clim. Change, 2, 1-5.

Yang. K., Ye, B., Zhou, D., Wu, B., Foken, T., Qin, J., Zhou, Z., 2011. Response of hydrological cycle to recent climate changes in the Tibetan Plateau. Climatic Change 9, 517-534.

Yang, K., Wu, H., Qin, J., Lin, C., Tang, W., and Chen, Y. 2014. Recent climate changes over the Tibetan Plateau and their impacts on energy and water cycle: A review. Global Planet. Chang. 112, 79-91.

Zhang, B., Wu, Y.H., Zhu, L.P., Wang, J.B., Li, J., Chen, D. 2011. Estimation and trend detection of water storage at Nam Co lake, central Tibetan Plateau. J. Hydrol. 405, 161-170.

Zhang, G., Yao, T., Xie, H., Wang, W., Yang, W., 2015. An inventory of glacial lakes in the Third Pole region and their changes in response to global warming. Global Planet. Chang. 131: 148-157

Zhang, X., Wu, Y., Zhang, X. 2014. Water level variation of inland lakes on the south-central Tibetan Plateau in 1972-2012. Acta Grographica Sinica, 69 (7), 993-1001.

Zhao, R., Ye, Q.H., Zong, J.B., 2016. Glacier and water storage changes in Peiku Co basin on Tibetan Plateau and its responses to the climatic changes. J. Arid Land Res. Environ. 30(2), 147-152.

Zhou, S., Kang, S., Chen, F., Joswiak, D.R., 2013. Water balance observations reveal significant subsurface water seepage from Lake Nam Co, south-central Tibetan Plateau. J. Hydrol. 491, 89-99.

Zhou, J., Wang, L., Zhang, Y., Guo, Y., Li, X., and Liu, W., 2015. Exploring the water storage 
changes in the largest lake (Selin Co) over the Tibetan Plateau during 2003-2012 from a basin-wide hydrological modeling. Water Resour. Res. 51, doi:10.1002/2014WR015846.

\section{Figures and captions}

Tab. 1 A general description of the satellite images used in this study.

Tab. 2 Areal changes of glacial lakes in Paiku Co basin between 1976 and 2015 (Unit: km²). Lake number is denoted in Fig. 1 (the lower left).

Fig. 1 Location of the study area. Point A represents the site where water levels were monitored and Points B and B' represent the sites where shorelines were investigated in 2016 and 2013, respectively. The black line is the catchment boundary of Paiku Co. The numbers in the lower left denote the glacial lakes.

Fig. 2 Isobath of Paiku Co. The right: Transects that the water depth was measured across the whole lake and the position of three water depth profiles. The middle: The isobath of Paiku Co. The left: Three water depth profiles.

Fig. 3 Seasonal lake level/storage changes between 2013 and 2017.

Fig. 4 Field investigations of the historical shorelines on Paiku Co's southeast shore. a) clear 
shorelines near the modern lake; b) Historical shorelines measured in the field; c) Distance and height of shorelines in 2016, 2006, 2001, 1994, 1988, and 1972, from the modern lake shore; d) Two-order polynomial regression between lake area and lake level changes.

Fig. 5 Reconstructed lake level/storage changes between 1972 and 2016. a) Changes in the highest (blue dots) and lowest (red dots) lake level between 1987 and 2016; b) Comparison between the reconstructed lake level (black dots) and satellite altimetry (red dots: magenta) between 2003 and 2014. The blue line represents daily lake level changes from in-situ observation.

Fig. 6 Changes in glacial lakes between 1976 and 2015. Lake number is denoted in both Tab. 1 and Fig. 1. The boundary of glacial lakes in 1976, 1990, 2000, 2010 and 2015 are marked.

Fig. 7 Changes in annual precipitation at Tingri and Nyalam County (green), and annual ice core accumulation at Dasuopu (red) and Mount Everest (blue). Annual ice core accumulation records at Dasuopu glacier and East Rongbuk Col come from Thompson et al., (2000) and Kaspari et al., (2008), respectively.

Fig. 8 Trend of monsoon precipitation (unit: mm, May to Sep) in Himalaya region between 1979 and 2015. The rectangular is the study region. The black line is the boundary of Himalayas. GPCP precipitation data (Version 2.3) are used in this study (https://www.esrl.noaa.gov/).

Fig. 9 Areal changes of Lake Cuojielong and Langqiang Co between 1972 and 2015. The location of the two lakes is marked in Fig. 1. 


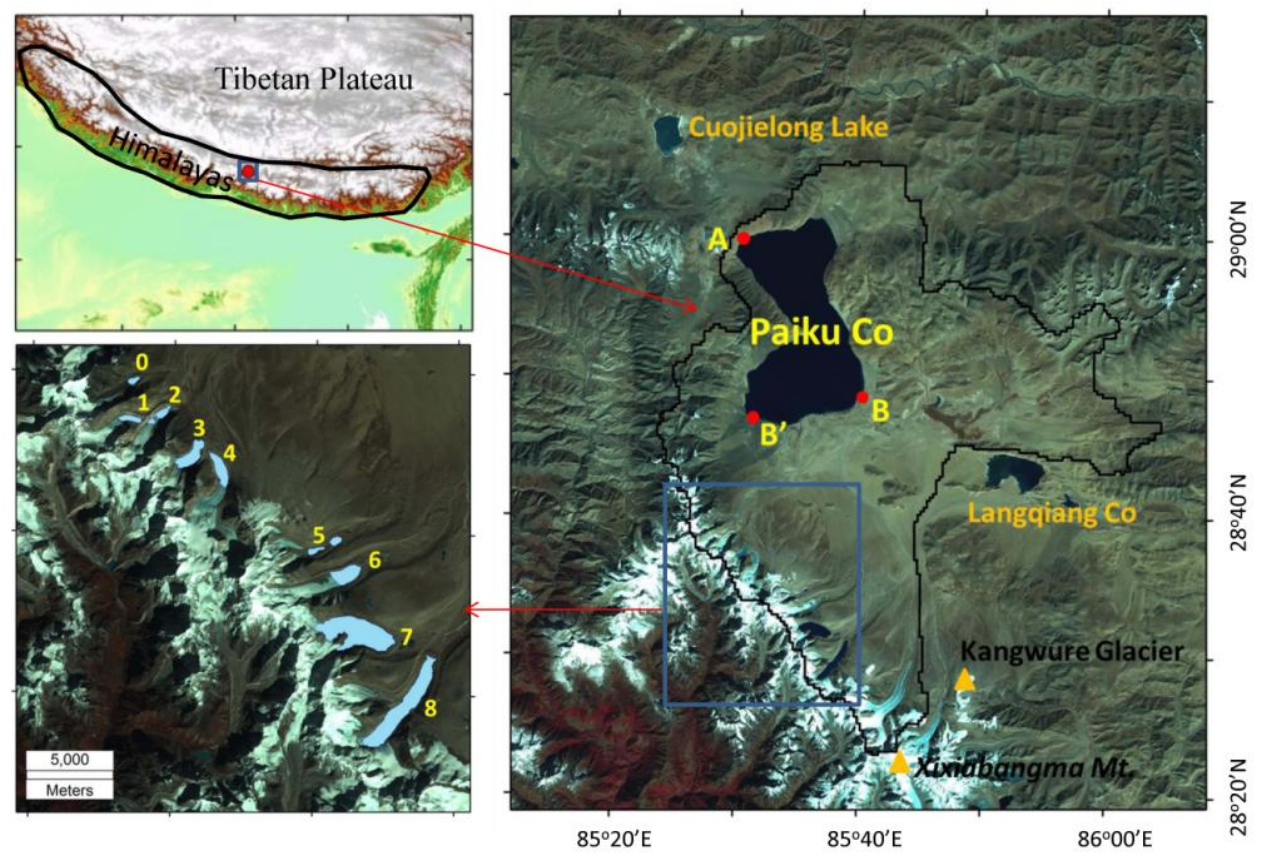



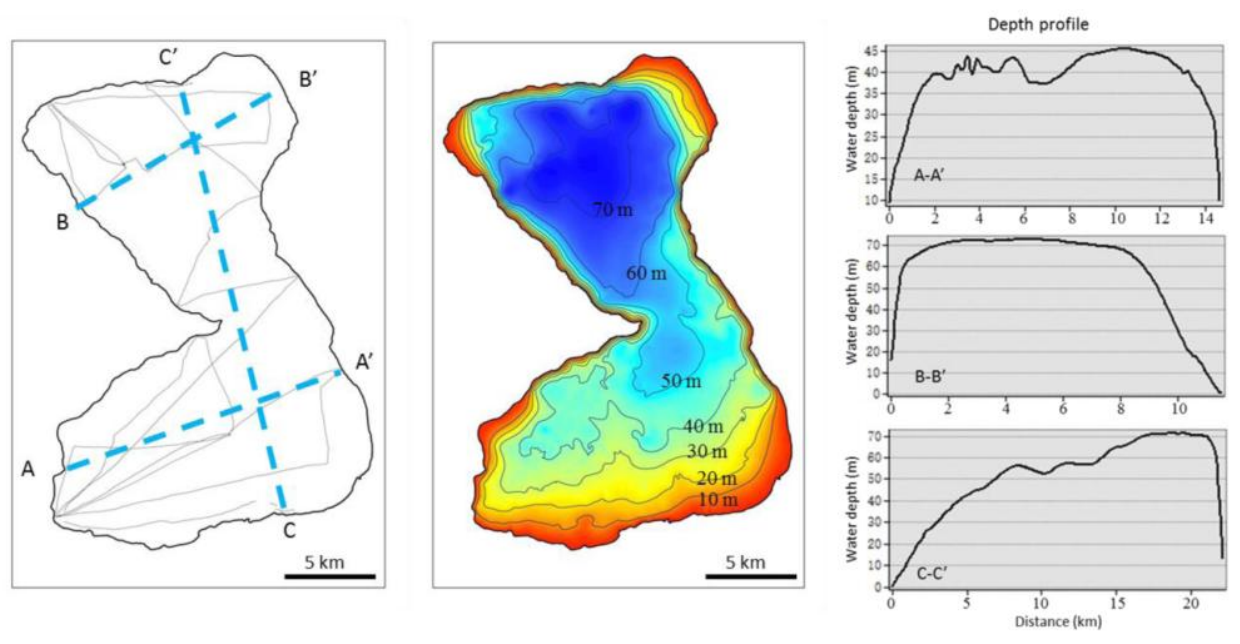

Fig. 2 


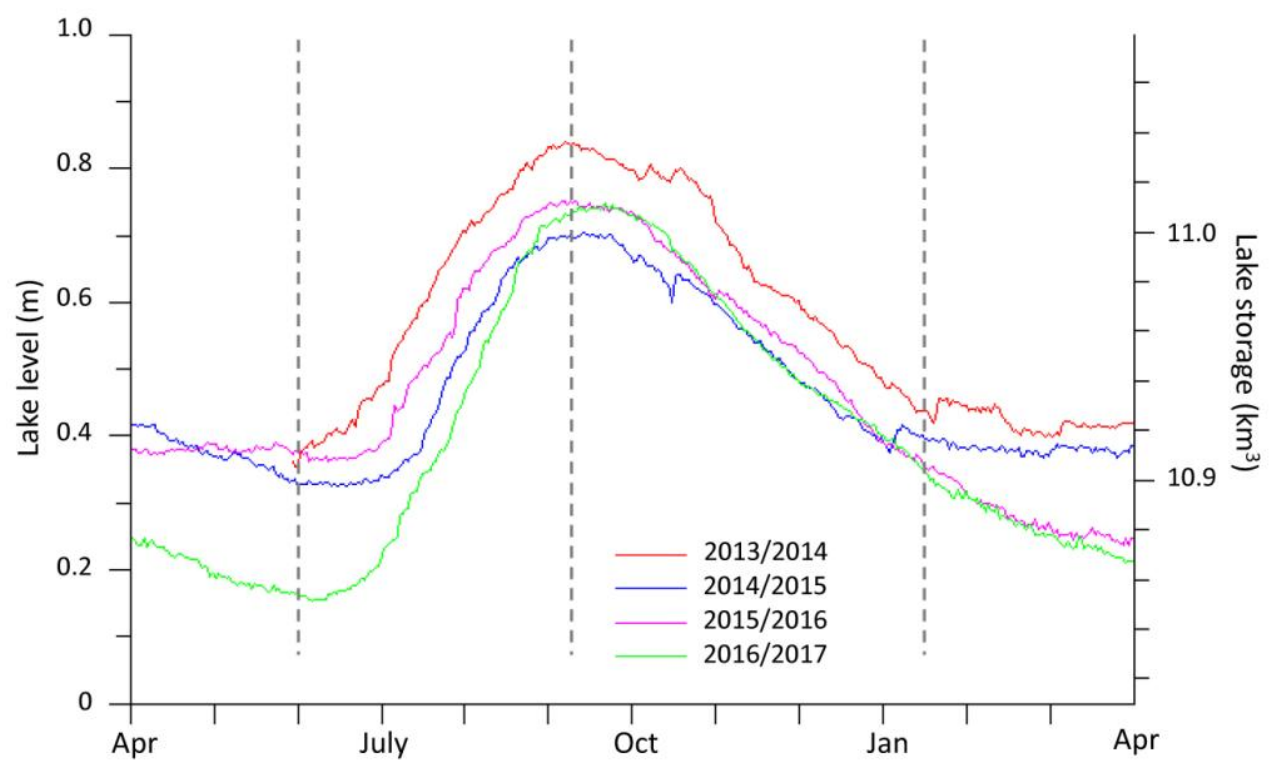



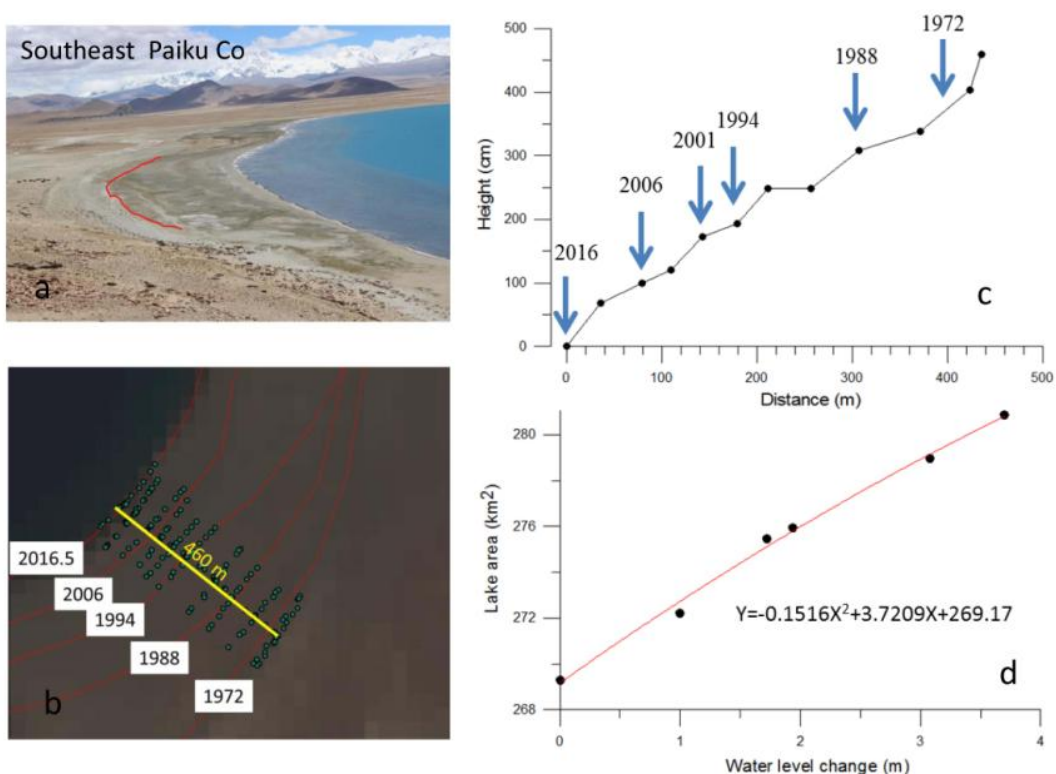


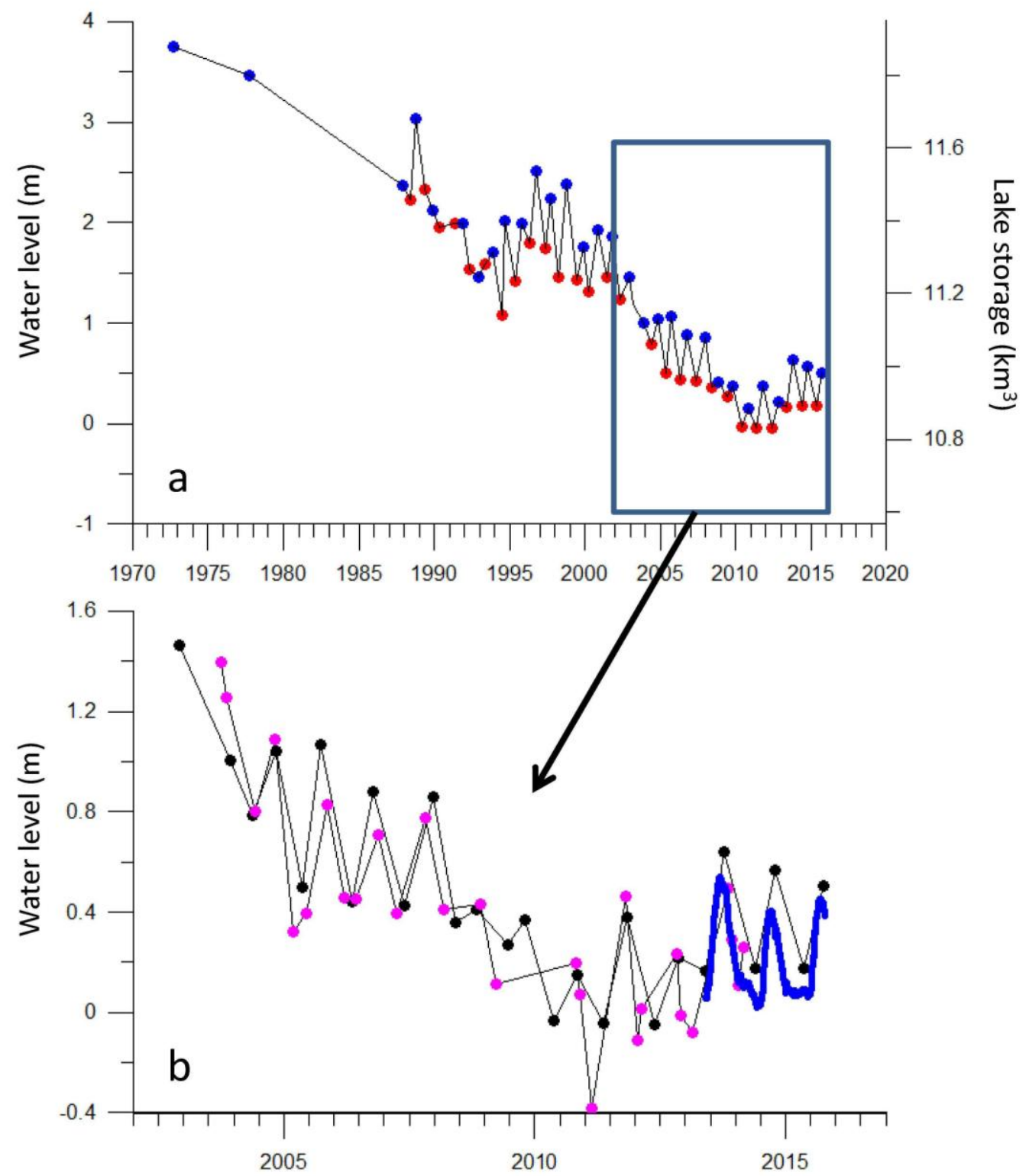




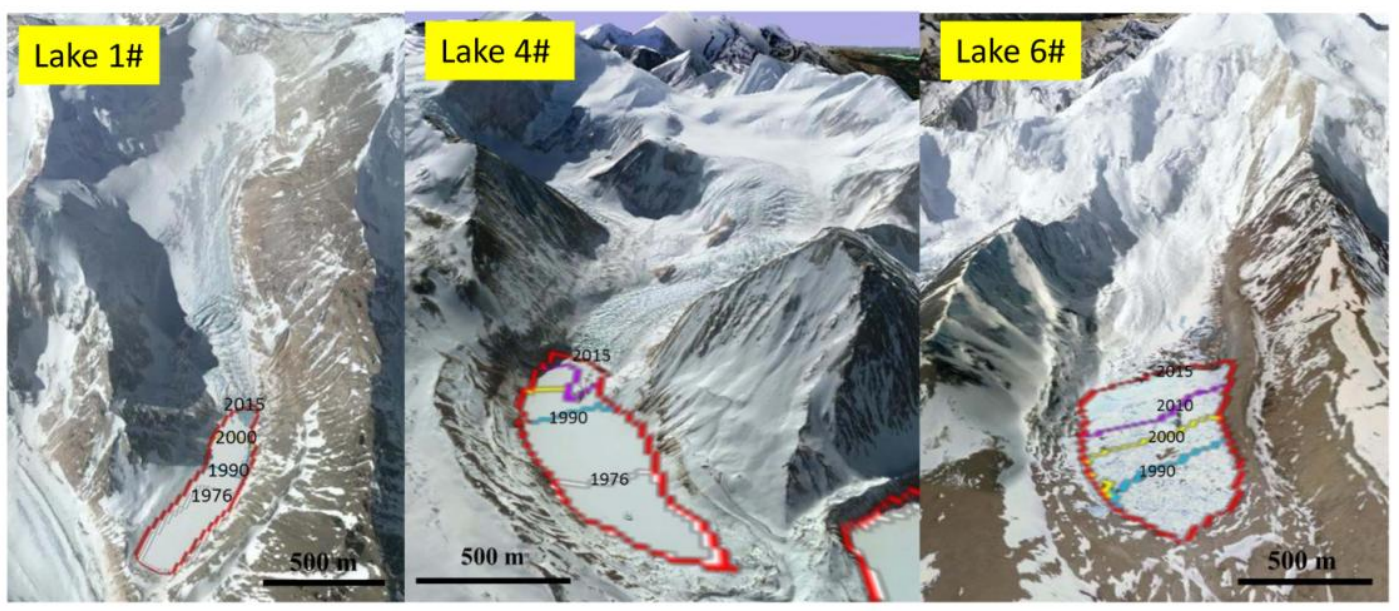




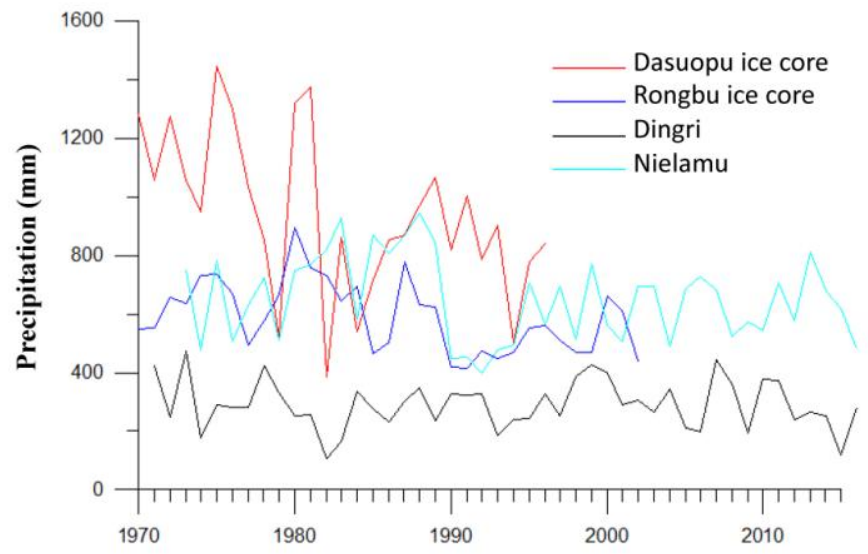




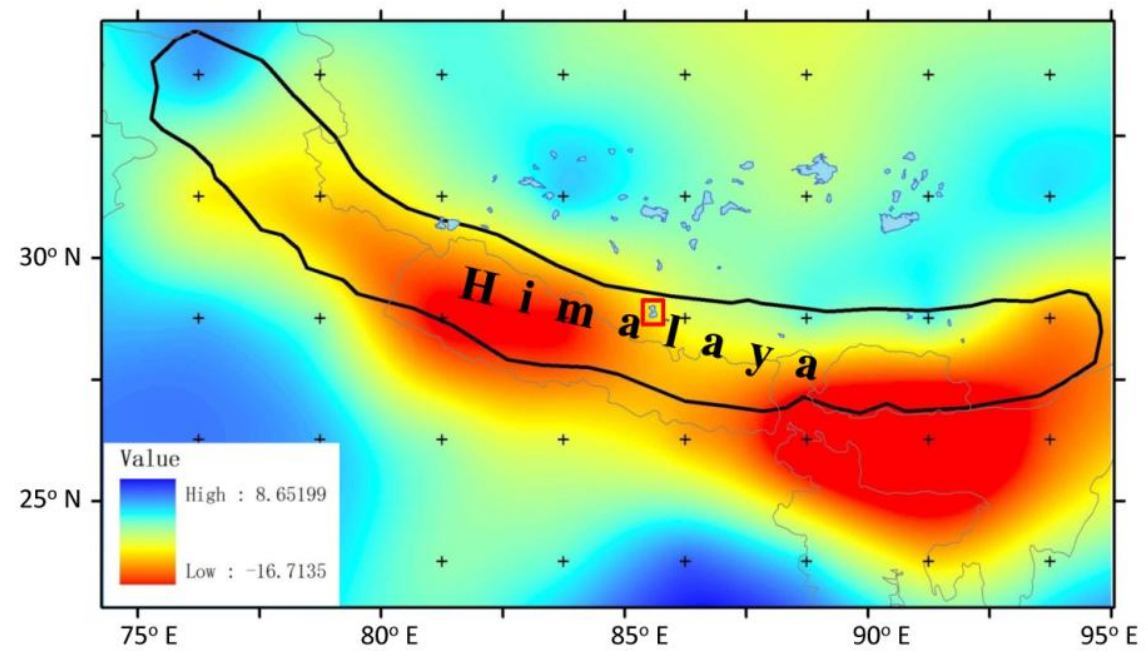



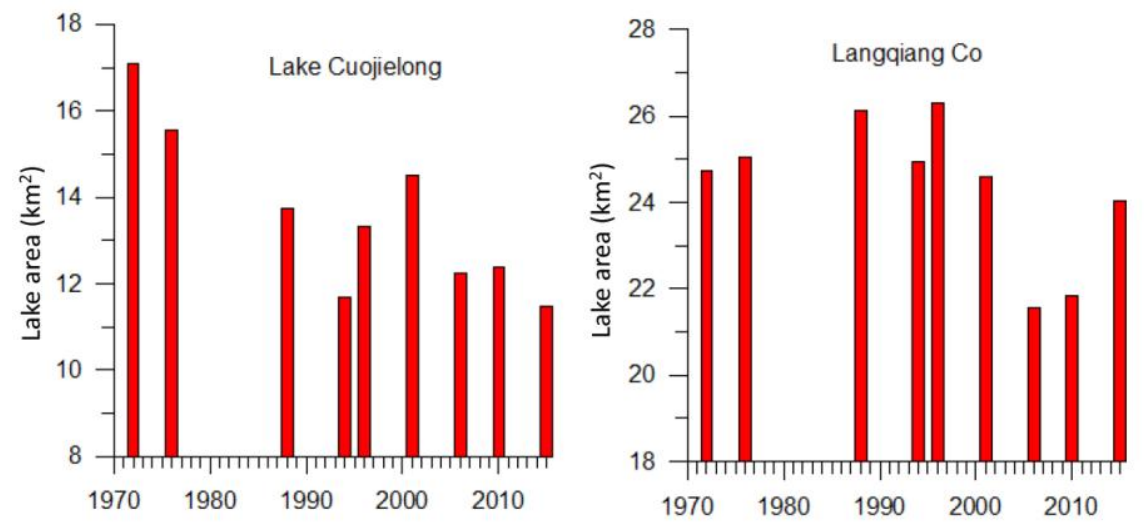
Tab. 1 A general description of the satellite images used in this study

\begin{tabular}{ccc}
\hline Data type & Acquisition time (Year/month/day) & Resolution \\
\hline Landsat & $1 \mathrm{~m})$ \\
MSS & $1987 / 12 / 13 ; 1988 / 6 / 6 ; 1988 / 10 / 12 ; 1989 / 5 / 8 ; 1989 / 12 / 2 ; 1990 / 5 / 19 ; 1991 / 5 / 14 ;$ & 60 \\
& $1991 / 11 / 30 ; 1992 / 5 / 16 ; 1992 / 12 / 10 ; 1993 / 5 / 19 ; 1993 / 11 / 11 ; 1994 / 6 / 23 ; 1994 / 9 / 11 ;$ & \\
Landsat & $1995 / 5 / 25 ; 1995 / 11 / 1 ; 1996 / 5 / 11 ; 1996 / 10 / 18 ; 1997 / 5 / 14 ; 1997 / 10 / 5 ; 1998 / 4 / 15 ;$ & 30 \\
4-5 TM & $1998 / 10 / 8 ; 2000 / 4 / 4 ; 2001 / 6 / 10 ; 2004 / 5 / 17 ; 2005 / 9 / 25 ; 2006 / 5 / 7 ; 2007 / 5 / 26 ;$ & \\
& $2008 / 5 / 28 ; 2009 / 6 / 16 ; 2009 / 10 / 22 ; 2010 / 5 / 18 ; 2011 / 10 / 28$ & 30 \\
Landsat 7 & $1999 / 6 / 5 ; 1999 / 12 / 6 ; 2000 / 11 / 22 ; 2001 / 10 / 24 ; 2002 / 5 / 4 ; 2002 / 11 / 28 ; 2003 / 12 / 1 ;$ & \\
ETM+ & $2004 / 11 / 1 ; 2005 / 5 / 12 ; 2006 / 10 / 6 ; 2007 / 12 / 28 ; 2008 / 10 / 27 ; 2010 / 11 / 2 ; 2011 / 5 / 13 ;$ & 30 \\
Landsat 8 & $2012 / 5 / 15 ; 2012 / 11 / 7 ; 2013 / 10 / 9 ; 2014 / 5 / 21 ; 2014 / 10 / 12 ; 2015 / 5 / 8 ; 2015 / 9 / 29$ & \\
OLI & $2013 / 5 / 26 ; 2016 / 06 / 03$ & \\
\hline
\end{tabular}


Tab. 2 Areal changes of glacial lakes in Paiku Co basin between 1976 and 2015 (Unit: km²). Lake number is denoted in Fig. 1 (right).

\begin{tabular}{cccccccc}
\hline Lake & & & Area & Area & Area & Area & Area \\
No. & Long. & Lat. & 2015 & 2010 & 2000 & 1990 & 1976 \\
\hline 0\# & 85.4755 & 28.6618 & 0.18 & 0.13 & 0.07 & 0.08 & Non-exist \\
$1 \#$ & 85.4741 & 28.642 & 0.35 & 0.35 & 0.31 & 0.23 & 0.18 \\
$2 \#$ & 85.4913 & 28.6441 & 0.42 & 0.21 & 0.13 & 0.09 & 0.04 \\
3\# & 85.5100 & 28.6234 & 1.19 & 1.2 & 1.19 & 1.15 & 0.77 \\
$4 \#$ & 85.5273 & 28.6162 & 1 & 0.92 & 0.85 & 0.74 & 0.28 \\
$5 \#$ & 85.5834 & 28.5748 & 0.22 & 0.18 & 0.14 & 0.08 & Non-exist \\
$6 \#$ & 85.6020 & 28.5625 & 1.23 & 0.82 & 0.6 & 0.36 & Non-exist \\
$7 \#$ & 85.6085 & 28.5323 & 5.39 & 5.33 & 5.23 & 5.1 & 4.99 \\
$8 \#$ & 85.6358 & 28.4942 & 4.89 & 4.86 & 4.88 & 4.77 & 4.1 \\
\hline total & & & 14.87 & 14.00 & 13.40 & 12.60 & 10.37 \\
\hline
\end{tabular}




\section{Highlights:}

Water storage at Paiku Co was estimated to be $109.3 \times 10^{8} \mathrm{~m}^{3}$ in June 2016

Lake level and water storage at Paiku Co decreased by $3.7 \pm 0.3 \mathrm{~m}$ and $(10.1 \pm 0.8) \times 10^{8} \mathrm{~m}^{3}$, respectively, between 1972 and 2015

Seasonal changes in lake level between 2013 and 2017 were demonstrated 